\title{
Local Value in Management of Fish Resource and Development of Law (Studies of Bajo Tribe in Gorontalo)*
}

\author{
Fenty U. Puluhulawa \\ Faculty of Law, State University of Gorontalo \\ Jenderal Sudirman Street No. 6 Gorontalo City, Indonesia \\ Tel./Fax: +62-435-821752 E-mail: fentyp@yahoo.com \\ Submitted: Sep 26, 2015; Reviewed: Oct 19, 2015; Accepted: Oct 26, 2015
}

\begin{abstract}
This article is intended to analyze the existence of local values that have become part of local wisdom prevailing in Bajo community. Type of research is legal anthropology, using interviews and focus group discussion. The results showed that the Bajo Gorontalo society, there are the local values associated with the management of fish resources in the sea. Local values mean that has been implemented since long time ago, and until this day the local values still remains valid. For the people of Bajo the values meant being a model society, thus forming a community adherence behavior in managing and treating fisheries resources in the sea, so that it becomes part of the public legal awareness. Therefore, it is important to identify the values that are still applicable and to make it as a basis for the development of laws related to fisheries, which is expected to be developed, as the expectations set forth in the legislation.
\end{abstract}

Keywords: Bajo Tribe; Law Development; Living Law; Local Value

\section{INTRODUCTION}

Gorontalo province known with its flagship program of the "storefront fishing" has the potential of marine fisheries are quite large, but has not been put to good use. ${ }^{1}$ Amount of fishery production, continued to increase over time. The results obtained from the Fisheries Inland Aquaculture in the amount of $115,477.39$ tons or $54.36 \%$ of the total

1 Debby Hariyanti Mano. (2013). "DPK Gelar Rakor Penanganan Tindak Pidana Perikanan". Available online at: www.antaragorontalo.com/berita/3200/ dpk-gelar-rakor-penanganan-tindak-pidanaperikanan [Accessed: April 5, 2014]. production is 212,427.50 tons and 95991 tons of the results of the 8413 Sea Fisheries fishery households. Seaweed acreage of approximately 14,250 hectares with a production of 99454.4 tons, while the total area of fisheries is $50,500 \mathrm{~km} 2$ with potential +92 171 tonnes/year. $^{2}$

Based on the existing potential, the management should be carried out according

2 Badan Penanaman Modal dan Pelayanan Terpadu Satu Pintu. (2015), "Perikanan dan Kelautan Provinsi Gorontalo". Available online at: http:// bpmptsp.gorontaloprov.go.id/potensi-perikanandan-kelautan [Accessed: Sept 25, 2015] 
to the principles outlined by the law, namely to increase the economy and sustainability in the management. Therefore, it should be to continue to preserve the function.

Relevant to this, the President through Presidential Instruction No. 15 of 2011 regarding the Protection of the Fisherman, has been set up and provide guarantees certainty and legal protection to the fishermen as well as to coordinate the steps necessary to prevent the arrests of fish illegal, unreported and unregulated, as well as destructive fishing in the management of the NKRI. In this context, it is expected that more policy emphasis on the things that are preventive and surveillance rather than efforts that are repressed. This condition must be different from the reality on the ground. Blast fishing in the waters of Gorontalo is already disturbing and damaging to the environment, so it needs to be prevented. Fish bombing is often done by fishermen and fishermen from outside the area itself. ${ }^{3}$

Empirical facts, damage to coral reefs in Gorontalo reach $40 \%$ of coastal power. Resource of costal area is on verge of destruction due to human activity. The cause is the rampant fishing is done illegally. This fact is feared more days will be more widespread. ${ }^{4}$ This reality will certainly give a

3 Antaranews. (2011). "Kapal Perang TNI Angkatan Laut Berpatroli Tangkal Bom Ikan". Available online at: www.antaranews.com/print/275787/ kapal-perang-tni-al-berpatroli-tangkal-bom-ikan [Accessed April 5, 2014].

4 Antarasulsel. (2012). "Kerusakan Terumbu Karang di Gorontalo Mencapai 40\%". Available online at: http://www.antarasulsel.com/berita/35377/kerusakan-terumbu-karang-gorontalo-capai-40-persen, [Accessed: December 7, 2013]. This information is the submission of the Head of Environment, Balihristi Gorontalo written by Antara media. Baca, Fenty U. Puluhulawa et al. (2014). "Pemanfaatan Alat Penangkap Ikan Tradisional Buili dan Peningkatan Kesadaran Hukum Masyarakat Nalayan negative impact on the preservation of the marine environment if it is not immediately anticipated. Therefore, we need a comprehensive approach to nature, which is expected to help resolve the issue. Bajo village is known as a fishing village since time immemorial the people that live in coastal areas generally work as fishermen. Bajo is unique from other communities, because the lives of those in coastal areas. Therefore, it is not surprising that the fishing community in this village, have traditional knowledge that have been implemented and adhered to hereditary.

Traditional knowledge, unique fishing tradition, knowledge of astrology, as a direction, and if the season will go to sea, so that nearby communities with nature. The ability to know the phenomena of nature through traditional knowledge (local knowledge) possessed a unique opportunity to continue to be developed so it can continue to be preserved and adhered to. It's not something that can be denied, that the development of technology, as well as the migration will cause fading/abolishment of the values of local wisdom, so there is a tendency to use technologies that have a negative impact on the environment (the technology is not environmentally friendly).

Relevant to the above description, Fisheries Law in Article 6 , paragraph 2 provides that the fisheries management, for the sake of catching and fish farming, are required to take into consideration customary law and or local knowledge and community participation. If it is associated with the pre-

dalam Rangka Perlindungan Sumber Daya Ikan di Desa Lamu Kecamatan Batudaa Pantai”. (Hibah Reports KKN-PPM which funded by DP2M DIKTI), pg. 2. 
vious description, the provisions of Article 6 , paragraph 2 provides the opportunity to develop the value of local knowledge possessed a basic framework in developing legal policies in the region In this article will describe the existence of local value Bajo communities in the management of fish resources, which is expected to be used in the development of the legal framework.

\section{METHOD}

This research is a legal anthropology. The research was conducted in the province of Gorontalo, by selecting the Torosiaje Jaya Village, Torosiaje Sea Village and Earth Bahari Village as a research location. The choice of location is based on the consideration being that located along the coast in the Tomini Bay. This location is known as a fishing village where Bajo tribe lives, which has a wide range of biodiversity, including the potential of fish resources. People living in the region generally have a livelihood as a fisherman. The fishermen who every day activities at sea have local knowledge, which support the activities of the fishing life in daily.

The primary data obtained by interviews and focus group discussion. Besides the primary data, this research was supported by secondary data. The data were analyzed qualitatively, based on data collection techniques that have been done.

\section{ANALYSIS AND DISCUSSION}

Local Values of Bajo Tribe and Legal Development

Legal development as usual development in other sectors, it should be carried out with at- tention or adopting back local values which are local wisdom that is still maintained as part of the public awareness in the area. Its knowledge traditionally done by local people over and over again, so that it becomes a habit that carried patterned by the community. This custom was originally done by the people in order to meet daily activities with limited facilities and infrastructure. Therefore has done repeatedly, then the pattern becomes a habit that is adhered to and carried from generation to generation, so that it becomes part of the public awareness that is obeyed by citizens in the territory of the region.

Solutions to keep the traditional knowledge that has a value of local knowledge is important and needs to be developed, namely in order to maintain the values that have long embraced, thus its continuity awake, of all kinds of potential threats to the spread of globalization and well the development of values that are inconsistent with the character and traits that evolved since the era of the ancestors of Indonesia. As for the values of traditional knowledge which has a value of local knowledge is usually carried out by groups of people consciously without pressure or sanction of the competent authority, and thus has no binding force will be continued for long periods of time.

Local knowledge is a form of knowledge, confidence, understanding, or insight that guide human behavior in life in ecological communities. ${ }^{5}$ Furthermore Nurjaya, that traditional wisdom rooted in values and re-

Sulaiman. (2011). "Kearifan Tradisional dalam Pengelolaan Sumber Daya Perikanan di Aceh pada Era Otonomi Khusus", Jurnal Dinamika Hukum, 11(2): 284-293. 
ligious system adopted in the community. ${ }^{6}$ based on the values and religion is the strong base to the community respect and implement those values. Even by some of these communities, always relate to things that are supernatural, so any violation will get the sanctions that are unseen as well. This is the underlying strength of these values continue to be maintained and implemented. Community Bajo known since ancient times as a sailors society. These communities have a uniqueness that are building a house in a relatively shallow sea area or on the coast and stay as well as their daily lives depend on the sea with the family.

Bajo communities spread across several regions such as Sulawesi, Southeast Sulawesi, Middle Sulawesi, and Gorontalo. The main source of income is derived from the marine community. Therefore, it is not surprising that people Bajo has expertise in catching fish, as well as support equipment at sea activities like traditional boats, traditional fishing gear, the ability to dive in the sea and so on. Traditional knowledge in the field of sea fishing as well as support activities that has the unique values, and typical of these communities, and this is certainly differentiated with other communities that do not originate from Bajo.

If evaluated toward potentials as well as the community's ability to catch fish, it should be able to increase the economic potential and empower groups of people living in the region. But in reality, this condition is still far from expectations. Therefore, efforts to continue to preserve and empower these communities through local wisdom es-

$6 \quad$ Ibid. poused the need to continue to do, so it is expected not only to contribute to society Bajo itself, but is also expected to contribute to the government district.

Fishing activities conducted by Bajo communities since time immemorial, so it is not surprising that this community has a life philosophy "Papu munang ita lino baka isi isina, bhatingga kita manusia nanganjama isi lino kaiya" which means "God has given us this world with all its contents, we as humans are thinking about how to manage it"? To people's lives Bajo , philosophy of life is upheld as the basis of life and is a source of motivation for the struggle of life since time immemorial to the present. Bajo community believes that the sea is the source of their life. Therefore, the existence of the sea needs to be maintained and preserved.

The law must be regarded as an expression of cultural values, meaning that the rule of law should be regarded as an expression of culture according to Soerjono Soekanto. ${ }^{8}$ The law is the concretization of the cultural values of society. Therefore, the existence of the law cannot be separated from the existence of society. Legal grow and develop in society dynamically, so its presence should be necessary to follow the development of society. In connection with the legal, cultural and social development, the discussions related to local moral values of a society are an interesting thing to be discussed, because the law in existence cannot be separated from society.

7 Zherly Amalia. (2013) "Antropologi Hukum". (Paper). Available online at: http://zherlyamalia. blogspot.co.id/2013/10/makalah-antropologihukum-suku-bajo.html, [Accessed April 16, 2015]. Hendra Wahanu Prabandani. (2011). "Pembangunan Hukum Berbasis Kearifan Lokal", Hukum dan Kearifan Lokal, Edisi 01, Tahun XVII, pg. 29. 
As previously described, the public Bajo Pohuwato in Gorontalo province has a habit that has been done for generations. Therefore, this habit has been done repeatedly in the long term, then this provision into law for the people of Bajo habit which, if violated, will get moral sanctions for violators themselves. For the people of Bajo, until now believed that any violation of this habit to get sanctions in the form of a warning from the spirits.

Awareness to continue carrying out habits that have a positive value is actually a capital base that is necessary to get the support and the support of the local government, so it will not become extinct along with the development and entry of various information which allows will give negative impact, which allows erosion of this habit, so it will only be part of a community history Bajo in Gorontalo Province.

In the legal system in Indonesia, recognition of local values have been listed in the constitution of RI that the 1945 Article 18B paragraph 2 which basically state shall recognize and respect the customary law community unit along with their traditional rights and legal values prevailing in society along the legal values are alive and in accordance with the development of society and the principles of the Unitary Republic of Indonesia which is regulated by law. This shows the recognition of the State of the rights of indigenous peoples as part of a public awareness is not contrary to the principle of the Homeland.

This provision is then adjusted further in various provisions relating to issues in environmental law regulated in the Law Num- ber 32 of 2009 regarding the Protection and Management of the Environment (hereinafter referred UUPPLH). In UUPPLH provisions also stipulated that the protection and management of the environment should pay attention to local values prevailing in the society. In UUPPLH explained that preserve the function of the environment and control pollution of occurrence as well as damage to the environment is the duty of every person (Article 67).

Therefore, the values that live in a society that is a form of environmental protection and management need to be maintained. In the field of fisheries, Act No. 45 of 2009 on Fisheries in Article 6 paragraph 2 that the management of fisheries for the benefit of fishing and fish empowerment should consider customary law and or local knowledge and participation of the community.

This list indicates the recognition of the State towards local values in a community system. Bajo community has a variety of local knowledge related to fisheries management. This local knowledge can be social capitalized. Social capital can be ethical, environmental wisdom, local legal norms. All of this needs to be taken into account in determining the development policy in the region. Therefore, it needs to be maintained and continue to be preserved for the progress of the region, so it can actually be the basis for regional progress. For example, communities of Bajo are one of the communities living in the coastal areas of the Gulf of Tomini Pohuwato Gorontalo province has a local culture that supports the preservation of environmental functions in the field of fisheries. 
Fishermen Bajo in Gorontalo Province, which has a value of environmental wisdom in the management of fisheries. Examples habit of doing fishing using traditional tools that are environmentally friendly, with space for the fish to spawn under the provisions of a specific time agreed upon by the traditional leaders, community Bajo know some traditions in fishing namely, palibu, pongka, sakai and lamma. Palibu is the activity of making a living on the sea in the local area which is usually done for a short period (2-3 days), pongka the conduct fishing activities carried out over several weeks/months, sakai was conducted over several months / years, lamma, sail boat carrying merchandise made up abroad for a period of annual. ${ }^{9}$

Habits are intended to have the values of environmental protection and management that have become part of legal awareness is done repeatedly since time immemorial hereditary. Such behavior may include ethics, beliefs, or standards of behavior applicable as the norms/rules of law that apply locally in the community, which, if breached, get moral sanction, even trusted and is associated with things that are mystical namely getting a warning from spirits. Standards of behavior as the norm/rule of law contains positive values for the environment of fish resources. Hence the need for the development of laws derived from the values of the local community, which has been recognized and implemented existence as part of legal awareness.

9 Ramli Utina. (2012). "Kecerdasan Ekologis dalam Kearifan Lokal Masyarakat Bajo Desa Torosiaje Provinsi Gorontalo", Proceedings and National Conference, Environmental Studies Center Indonesia XXI. Mataram, Sept 13-15, 2012, pg. 5

\section{CONCLUSION}

Based on the above, it can be concluded that the community of Bajo community has a local value in society. Local values are recognized and implemented by communities, so it is a law of life in the midst of society. Legal development should be based on local values, so it is expected to be effective invalidity in the community.

\section{ACKNOWLEDGEMENT}

Thanks go to the Islamic Development Bank in Project Seven in One, has been financing activities Leading Universities Research Grants, which began in 2015 . The same remarks submitted to the Local Government Pohuwato and Bajo Gorontalo Society, incorporated in Kelompok Masyarakat Sadar Lingkungan (KSL).

\section{BIBLIOGRAPHY}

Hendra Wahanu Prabandani. (2011). "Pembangunan Hukum Berbasis Kearifan Lokal", Hukum dan Kearifan Lokal, Edisi 01, Tahun XVII.

Ramli Utina. (2012). "Kecerdasan Ekologis dalam Kearifan Lokal Masyarakat Bajo Desa Torosiaje Provinsi Gorontalo", Proceedings and National Conference, Environmental Studies Center Indonesia XXI. Mataram, Sept 13-15, 2012

Sulaiman. (2011). "Kearifan Tradisional dalam Pengelolaan Sumber Daya Perikanan di Aceh pada Era Otonomi Khusus", Jurnal Dinamika Hukum, 11(2): 284-293. 
Other sources:

Antaranews. (2011). "Kapal Perang TNI Angkatan Laut Berpatroli Tangkal Bom Ikan". Available online at: www. antaranews.com/print $/ 275787 / \mathrm{kapal}-$ perang-tni-al-berpatroli-tangkal-bomikan [Accessed April 5, 2014].

Antarasulsel. (2012). "Kerusakan Terumbu Karang di Gorontalo Mencapai 40\%”. Available online at: http://www.antarasulsel.com/berita/35377/kerusakanterumbu-karang-gorontalo-capai40-persen, [Accessed: December 7, 2013].

Badan Penanaman Modal dan Pelayanan Terpadu Satu Pintu. (2015), "Perikanan dan Kelautan Provinsi Gorontalo".
Available online at: http://bpmptsp. gorontaloprov.go.id/potensi-perikanan-dan-kelautan [Accessed: Sept 25, 2015]

Debby Hariyanti Mano. (2013). "DPK Gelar Rakor Penanganan Tindak Pidana Perikanan". Available online at: $\underline{w w w}$. antaragorontalo.com/berita/3200/ dpk-gelar-rakor-penanganan-tindakpidana-perikanan [Accessed: April 5, 2014].

Zherly Amalia. (2013) "Antropologi Hukum”. (Paper). Available online at: http://zherlyamalia.blogspot.co.id/ 2013/10/makalah-antropologi-hukumsuku-bajo.html, [Accessed April 16, 2015]. 